\title{
Anti-obesity Effects of Curcuma longa L. Extracts through Inhibiting Adipogenic Transcription Factors
}

\author{
Seong-Ae Lee ${ }^{1}$, Hyeong-Jin Ju ${ }^{1}$, Min-Jun Park ${ }^{1}$, Bu-Duk Park ${ }^{2}$, Gyo-Nam Kim ${ }^{1 *}$ \\ ${ }^{1}$ Department of Food, Nutrition and Biotechnology, Kyungnam University, Changwon-si, Gyeongsangnam-do, Korea \\ ${ }^{2}$ Balhyochon, Gyeongsan-si, Gyeongsangbuk-do, Korea
}

\author{
*Corresponding author: Gyo-Nam Kim, \\ Department of Food, Nutrition and \\ Biotechnology, Kyungnam University, 7 \\ Kyungnamdaehak-ro, Masanhappo-gu, \\ Changwon-si, Gyeongsangnam-do 51767, Korea \\ Tel.: +82552496330 \\ Fax: +82 5059992171 \\ Email: gnkim@kyungnam.ac.kr
}

Received February 28, 2017

Revised April 19, 2017

Accepted April 20, 2017

Published June 30, 2017

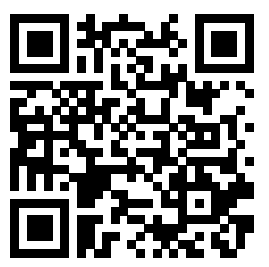

\begin{abstract}
Purpose: Curcuma longa L. (CL) has been widely used as a medicinal herb and spice. Although several biological effects, such as anti-oxidant and anti-inflammatory effects, of CL have been reported, its anti-adipogenic effects as a nutri-cosmetic material are relatively unclear. This study aimed to evaluate the anti-oxidant and anti-adipogenic effects of CL extracts (CLE) in 3T3-L1 adipocytes. Methods: The 2,2-diphenyl-1picrylhydrazyl (DPPH) radical-scavenging activity of CLE was tested. Cell viability was evaluated by a thiazolyl blue tetrazolium bromide (MTT) assay. The anti-adipogenic effects of CLE were estimated using Oil Red O (ORO) staining in 3T3-L1 adipocytes. In addition, number and size of lipid droplets were determined by photomicrograph analysis. The mRNA expression levels of adipogenic transcriptional factors in CLEtreated 3T3-L1 adipocytes were analyzed by reverse transcription-polymerase chain reaction (RT-PCR). Results: Up to $10 \mathrm{mg} / \mathrm{mL}$ concentration of CLE effectively scavenged DPPH radicals. Treatment with up to $800 \mu \mathrm{g} / \mathrm{mL}$ concentration of CLE for $24 \mathrm{~h}$ did not affect 3T3-L1 adipocytes viability. Thus, we chose up to $800 \mu \mathrm{g} / \mathrm{mL} \mathrm{CLE}$ for further experiments. Treatment with CLE significantly inhibited lipid accumulation, and decreased number and size of lipid droplets in 3T3-L1 adipocytes. In addition, down-regulated CCAAT/enhancer binding protein $\beta$ (CEBPB), peroxisome proliferator activated receptor $\gamma(P P A R G)$, CCAAT/enhancer binding protein $\alpha(C E B P A)$, fatty acid synthase $(F A S N)$, and lipoprotein lipase $(L P L)$ expression levels were observed in CLE treated 3T3-L1 cell. Conclusion: Our results suggest that CLE could be used as a potential nutri-cosmetic material that exhibits anti-oxidant and anti-adipogenic effects.
\end{abstract}

Keywords: Curcuma longa L., Obesity, Adipogenesis, Anti-oxidant effects, Oxidative stress

\section{Introduction}

비만은 에너지 섭취와 소비간의 불균형으로 인해 체지방이 과잉 축적되어있는 상태를 일컫는다(Chua \& Leibel, 1997). 비만은 정신 적, 유전적, 그리고 내분비계 장애 등을 비롯한 다양한 원인들로 인 해 발생하는 것으로 알려져 있으며, 그 중 체내의 산화적 스트레스 (oxidative stress) 또한 비만, 당뇨, 그리고 암 등을 비롯한 만성질 환의 주요한 원인으로 알려져 있다.

비만의 다양한 요인 중 하나로 보고되는 산화적 스트레스는 비 만 외에도 인슐린 저항성, 그리고 고혈압 등 여러 만성질환과 밀접 하게 관련되어 있다(Salla et al., 2016). 체내의 에너지 생산 과정에 있어 활성산소(reactive oxygen species)의 발생은 필수불가결한 요
소이다. 활성산소의 정상적인 생산은 정상세포의 성장, 증식 및 분 화 등에 긍정적으로 관여하지만, 이 활성산소의 농도가 과도하게 증가하게 되면 체내의 항산화 방어 시스템이 무너지게 되고 이는 체내 산화적 스트레스를 유발하게 된다(Evans et al., 2002). 고지방 과 고콜레스테롤 상태에서 산화적 스트레스는 더욱 촉진되는데, 이 때 체내 항산화 시스템이 충분히 활성화 되지 못하면 자유라디칼을 제거하는 항산화 방어기전의 불균형을 초래하게 되고, 심혈관계 질 환이 유발된다(Jakoby, 1978). 따라서, 항비만 천연물 소재의 탐색에 있어 항산화 활성을 검증하는 것은 중요한 부분 중 하나로 판단된다. 비만의 직접적인 원인은 비정상적인 지방세포의 숫자 및 크기 의 증가로 보고되고 있으며, 지방세포는 지방조직에서 분비되는 생체조절물질인 아디포카인(adipokine)의 생산과 분비를 통해 비 
만 및 관련 대사질환 발병을 야기한다고 알려져 있다(de Ferranti \& Mozaffarian, 2008; Holst \& Grimaldi, 2002). 지방세포의 숫 자 및 크기는 전지방세포의 지방세포로의 분화과정(adipogenesis) 에 의하여 증가되어 체내에 축적된다. 이러한 adipogenesis의 기 전을 조절하는 것이 항비만의 효과적인 치료법이라고 알려져 있다 (Cao et al., 1991). Adipogenesis 관련 실험에는 in vitro cell model system 중 mouse embryo로부터 유래된 3T3-L1 지방전구세포를 주로 사용한다. Adipogenesis는 지방세포형성 과정 중에 단백질 및 유전자 발현, 호르몬 민감성 등의 여러 인자에 작용을 받게 된다 (Koutnikova \& Auwerx, 2001; Rosen \& Spiegelman, 2000). 지방 분화과정유도에 필수적인 여러 전사인자들은 발현되는 양과 시기, 전사인자간의 상호조절 등을 통하여 제어가 된다. 분화과정에서의 유전자 발현에는 초기분화에 관여하는 CCAAT/enhancer binding proteins $(C E B P)$ 에 속한 $C E B P B$ 와 CCAAT/enhancer binding protein $\delta(C E B P D)$, 분화중기에 조절되는 $P P A R G$ 와 $C E B P A$ 를 중 심으로 세포분열유도 물질과 함께 분화가 시작된다(Chen et al., 2005; Zhang et al., 2004). Adipogenesis의 핵심조절인자로 알려 진 $\mathrm{PPARG}$ 와 $\mathrm{CEBPA}$ 는 상호작용을 하여 상승효과를 불러일으켜 adipogenesis의 후기 전사인자의 발현을 증가시킨다(Morrison \& Farmer, 2000; Rosen \& MacDougald, 2006).

이러한 연구결과들을 바탕으로 최근 합성 항산화제를 대체할 수 있는 천연 항산화제와, 전지방세포로부터 지방세포로 분화되는 과 정을 억제하여 비만을 예방하고자 천연유래 소재에 대한 다양한 연 구가 진행되고 있다(Choi et al., 2012; Lee et al., 2012a).

울금(Curcuma longa L.)은 생강과에 속하며 인도, 중국, 미얀마 그리고 우리나라 진도군에서 재배되고 있다. 울금은 덩이뿌리 또 는 주피를 제거한 형태로 찌거나 말려 사용하며, 현재 한약재, 식 품의 향신료, 음료, 그리고 차 등으로 식품산업에서 다양하게 활 용되고 있다(Jelodar et al., 2005). 울금의 주요한 생리활성 성분 은 커큐민(curcumin), 데메톡시커큐민(demethoxycurcumin), 그리 고 비스데메톡시커큐민(bisdemethoxycurcumin)으로 알려져 있으 며(Lee et al., 2012b), 이들을 이용한 항산화(Barry et al., 2009), 항암(Mudduluru et al., 2011), 그리고 항비만 활성(Kim et al., 2013a) 등이 보고되었다. 그러나, 앞선 연구들에서 강황(Curcuma aromatica)과 울금이 혼용되거나, 대부분이 동남아시아 지역 유래 의 울금을 활용한 것으로 조사되어 국내산 울금에 대한 생리활성 평가가 요구된다.

따라서 본 연구에서는 $\mathrm{DPPH}$ 라디칼 소거를 통한 울금 추출물 (CLE)의 항산화 활성을 평가하고, 더불어 3T3-L1 세포에서 CLE 가 지방세포분화과정에서 지방 축적에 어떻게 작용을 하는지 알아 보고자 하였다. 또한 CLE 처리가 adipogenesis 과정에 관여하는 유전자 및 전사인자들의 특이적 발현에 어떻게 영향을 미치는지 알 아봄으로써, 국내산 울금의 화장품 및 미용식품 소재로서의 가능성 을 평가하였다.

\section{Methods}

\section{1. 실험재료}

본 실험에 사용된 국내 진도산 CLE는 (주)삼진내추럴(Korea)에서 구입하여 사용하였다. CLE의 제조는 $1 \mathrm{~kg}$ 의 울금을 증류수 $10 \mathrm{~L}$ 에 희석하여 $100 \pm 5^{\circ} \mathrm{C}$ 에서 가열 및 추출한 후, 1 차 매쉬망 및 2 차 필 터를 통해 여과하였으며 최종 65 brix에 농축을 종료하여 제조되었 다. MTT, ORO, 3-isobutyl-1-methylxanthine (BMMX), insulin, vitamin $\mathrm{C}$ (L-ascorbic acid), dexamethasone (DEX)은 SigmaAldrich (USA)에서 구매하여 사용하였다. Dulbecco's modified Eagle's medium (DMEM), antibiotics (penicillin-streptomycin mixture), bovine calf serum (BCS), fetal bovine serum (FBS)는 Welgene (Korea)에서 구입하여 사용하였으며, ORO staining에 사 용된 dimethyl sulfoxide (DMSO), 2-propanol은 Junsei Chemical (Japan)에서 구입하였다. Formaldehyde는 Bio Basic (USA)에서 구입하였으며, RT-PCR 분석에 사용한 TRIzol ${ }^{\circledR}$ 은 Invitrogen ${ }^{\mathrm{TM}}$, Thermo Fisher Scientific (USA), AccuPower ${ }^{\circledR}$ CycleScript RT PreMix는 Bioneer (Korea)에서 구매하여 사용하였다. 본 실험에서 사용된 3T3-L1 전지방세포는 한국세포주은행(Korea)에서 분양 받 아 사용하였다.

\section{DPPH 라디칼 소거활성}

$\mathrm{CLE}$ 의 항산화 활성은 $\mathrm{DPPH}$ 라디칼 소거활성을 이용하여 평가 하였다. DPPH 라디칼 소거능은 Chen et al. (1998)의 방법을 일부 변형하여 실험을 진행하였다. $190 \mu \mathrm{L}$ 의 $\mathrm{DPPH}(190 \mu \mathrm{M})$ 에 농도별 $\mathrm{CLE}$ 를 $10 \mu \mathrm{L}$ 를 가하여 $37^{\circ} \mathrm{C}$ incubator에서 $30 \mathrm{~min}$ 동안 반응시킨 후, microplate reader (VersaMax; Molecular Devices, USA)를 이용하여 $517 \mathrm{~nm}$ 에서 흡광도를 측정하였다. 본 실험에서는 수용성 항산화제인 vitamin $\mathrm{C}$ 를 양성 대조군으로 사용하였다. CLE를 처 리하지 않은 $\mathrm{DPPH}$ 를 대조군으로 하여 $\mathrm{CLE}$ 의 $\mathrm{DPPH}$ 라디칼 소거 활성을 계산하였다.

\section{3T3-L1 세포에서 CLE의 세포독성 평가}

$\mathrm{CLE}$ 의 항비만 활성을 평가하기 전, 3T3-L1세포에 미치는 CLE 의 세포독성을 알아보고자 MTT assay를 실시하였다. $100 \%$ 포화 상태(confluent)가 된 3T3-L1의 세포에 CLE를 10, 50, 100, 200, $400,800 \mu \mathrm{g} / \mathrm{mL}$ 의 농도로 $24 \mathrm{~h}$ 동안 처리한 후, 배지를 완전히 제 거하고 BCS-DMEM에 희석한 MTT 시약 $200 \mu \mathrm{g} / \mathrm{mL}$ 을 처리하 여 $37^{\circ} \mathrm{C} \mathrm{CO}$ incubator에서 $1 \mathrm{~h}$ 동안 배양하였으며, 반응 후 배지 를 완전히 제거하고 $300 \mu \mathrm{L}$ 의 $\mathrm{DMSO}$ 를 이용하여 각 세포의 보라 색 formazan을 녹여주었다. DMSO에 녹인 formazan을 96-well plate에 $100 \mu \mathrm{L}$ 씩 분주하여 microplate reader를 이용하여 $570 \mathrm{~nm}$ 에서 흡광도를 측정하였다. CLE를 처리하지 않은 3T3-L1 전지방 세포를 대조군으로 하여 CLE의 세포독성을 분석하였다. 


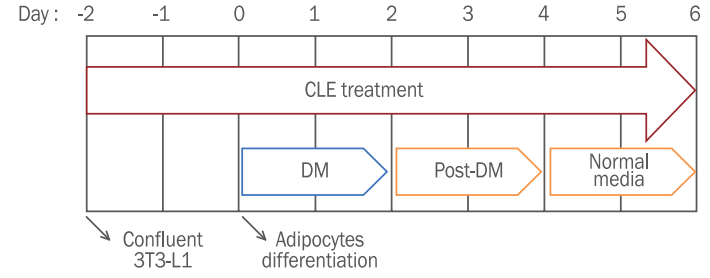

Figure 1. Scheme of 3T3-L1 differentiation and CLE treatment. Two days post-confluency was designated as day 0. 3T3-L1 adipocytes were treated with CLE during day -2 to day 6 . Two days after confluency (day 0), cells were cultured using a DM. After differentiation, the media was replaced with a post-DM. Thereafter, cells were cultured in normal media and the media was changed every 2 days. CLE, Curcuma longa L. extracts; Normal media, mixture media of $10 \%$ fetal bovine serum, $1 \%$ penicillin-streptomycin, and Dulbecco's modified Eagle's medium; DM, differentiation media comprising normal media, $500 \mu \mathrm{M}$ 3-isobutyl-1-methylxanthine, $5.2 \mu \mathrm{M}$ dexamethasone, and $167 \mathrm{nM}$ insulin; Post-DM, postdifferentiation media comprising normal media and $167 \mathrm{nM}$ insulin.

\section{3T3-L1 세포배양 및 지방세포 분화}

3T3-L1 전지방세포는 10\% (v/v) BCS와 1\% (v/v) penicillinstreptomycin을 첨가한 DMEM에서 $100 \%$ 포화상태가 될 때까지 $37^{\circ} \mathrm{C} \mathrm{CO}$ incubator에서 배양하였다. 3T3-L1의 지방세포 분화 및 $\mathrm{CLE}$ 처리는 Figure 1과 같이 진행하였다. 본 실험에서는 3T3L1 전지방세포가 $100 \%$ 포화상태가 되었을 때를 day -2 로 표기 하였다. 지방세포 분화유도 배지로는 $10 \%$ (v/v) FBS와 $1 \%(\mathrm{v} / \mathrm{v})$ penicillin-streptomycin을 첨가한 DMEM에 $500 \mu \mathrm{M}$ IBMX, 5.2 $\mu \mathrm{M}$ DEX, $167 \mathrm{nM}$ insulin을 포함한 differentiation media (DM)을 이용하여 day 0 부터 day 2 까지 $48 \mathrm{~h}$ 동안 처리하였고, 분화유도 후 post-differentiation media (Post-DM)은 10\% (v/v) FBS와 1\% (v/v) penicillin-streptomycin이 첨가된 DMEM에 $167 \mathrm{nM}$ insulin 만을 첨가하여 day 2 부터 day 4 까지 처리하였다. Day 4 부터 day 6 까지는 $10 \%$ (v/v) FBS와 $1 \%$ (v/v) penicillin-streptomycin이 첨가된 $\mathrm{DMEM}$ 으로만 $48 \mathrm{~h}$ 동안 처리하였고, day 6 에 지방세포 분 화를 종료하였다.

\section{Adipogenesis 억제활성 평가}

$\mathrm{CLE}$ 의 항비만 활성을 평가하고자, 3T3-L1 전지방세포를 지방세 포로 분화시키고 CLE의 adipogenesis 억제활성은 $\mathrm{ORO}$ 염색법을 이 용하여 평가하였다. 3T3-L1 세포를 지방세포로 분화시키면서 CLE 를 $50,100,200,400,800 \mu \mathrm{g} / \mathrm{mL}$ 의 농도로 지방세포 분화과정 동 안 전 기간 처리하고, day 6 에 $\mathrm{ORO}$ 염색을 실시하였다. 실온에서 배 지를 모두 제거하고 phosphate buffered saline (PBS; pH 7.4)으로 세척 후, $3.7 \%$ (v/v) formaldehyde를 $0.5 \mathrm{~mL}$ 씩 첨가하여 분화종료 한 3T3-L1 지방세포를 $30 \mathrm{~min}$ 동안 고정시켰다. Formaldehyde를 제거하고 흐르는 물에 3 번 세척 후 $3 \mathrm{mg} / \mathrm{mL}$ 농도의 $\mathrm{ORO}$ 시약으로 shaker (D500; LaboGene, Korea)를 이용하여 $15 \mathrm{~min}$ 동안 염색하 였다. 현미경을 통하여 CLE 처리가 지방세포의 지방구 수와 크기에 영향을 미치는지 이미지 분석하였으며, 세포 내에 축적된 지방에 염 색된 $\mathrm{ORO}$ 는 $\mathrm{DMSO}$ 를 $300 \mu \mathrm{L}$ 씩 넣어 용해시킨 후 96-well plate에 $100 \mu \mathrm{L} /$ well씩 분주하여 $510 \mathrm{~nm}$ 에서 microplate reader를 이용하여 흡광도를 측정하였다. CLE를 처리하지 않은 지방세포(day 6)를 대 조군으로 하여 지방 축적량을 계산하였다.

\section{RT-PCR을 통한 유전자 발현 분석}

3T3-L1 세포를 adipogenesis 억제활성 평가방법과 동일하게 지 방세포로 분화시키면서, CLE의 농도는 $10,100,200,400 \mu \mathrm{g} / \mathrm{mL}$ 까지 지방세포분화 전 기간 동안 처리하였다. 총 $\mathrm{RNA}$ 를 day 6 에 $\mathrm{TRIzO}^{\circledR}$ 을 이용하여 추출한 후, chloroform을 $100 \mu \mathrm{L}$ 씩 첨가하여 $15 \mathrm{~s}$ 동안 잘 혼합하였다. Centrifuge (1580R; LaboGene)를 이용하 여 $17,000 \mathrm{rpm}, 20 \mathrm{~min}$ 의 조건에서 원심 분리하여 상층액을 얻은 후, 상층액에 $250 \mu \mathrm{L} 2$-propanol을 첨가하고 $17,000 \mathrm{rpm}$ 에서 15 $\mathrm{min}$ 동안 재 원심 분리하여 $\mathrm{mRNA}$ 를 분리하였다. 분리한 $\mathrm{mRNA}$ 는 RNase-free water로 용해하여 정량한 뒤 $\mathrm{cDNA}$ 를 합성하였 다. Thermal cycler (T100* ${ }^{\text {Tw }}$ Bio-Rad Laboratories, USA)를 이용 하여 합성된 $\mathrm{cDNA}$ 로 $\mathrm{PCR}$ 을 수행한 후에 $1.5 \%(\mathrm{w} / \mathrm{v})$ agarose gel 에 DNA marker와 함께 조건의 시간 동안 전기영동 하여 유전자 발 현수준을 분석하였다. RT-PCR 분석의 internal control로는 actin beta (ACTB)을 사용하였으며 본 실험에서 사용된 대상 유전자들의

Table 1. Primer sequences for RT-PCR analysis

\begin{tabular}{lll}
\hline Primer & Forward $\left(5^{\prime} \rightarrow 3^{\prime}\right)$ & Reverse $\left(5^{\prime} \rightarrow 3^{\prime}\right)$ \\
CEBPB & GCAAGAGCCGCGACAAG & GGCTCGGGCAGCTGCTT \\
PPARG & CCATTCTGGCCCACCAACTT & CCTTCTCGGCCTGTCGATCC \\
CEBPA & CCAGAGGATGGTTTCGGGTC & TCCCCAACACCTAAGTCCCT \\
$F A S N$ & CCTCTTCCTGTTTGACGGCT & GATCGGAGCATCTCTGGTGG \\
$L P L$ & AAACCCCAGCAAGGCATACA & ATTTGTGGAACCTCGGGCA \\
ACTB & AGGGAATCGTGCGTGACAT & AGCTCAGTAACAGTCCGCCT \\
\hline
\end{tabular}

RT-PCR, reverse transcription-polymerase chain reaction; $C E B P B, C C A A T /$ enhancer binding protein $\beta ; P P A R G$, peroxisome proliferator activated receptor $\gamma_{\text {; }} C E B P A$, CCAAT/enhancer binding protein $\alpha ; F A S N$, fatty acid synthase; $L P L$, lipoprotein lipase; $A C T B$, actin beta. 


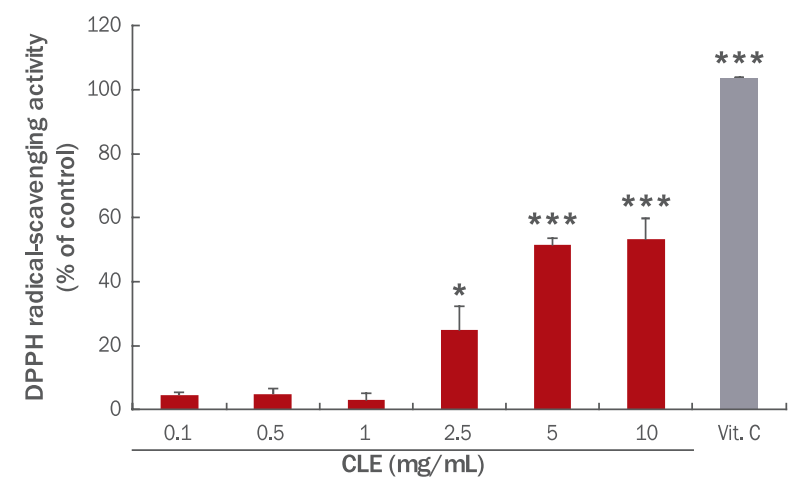

Figure 2. DPPH radical-scavenging activity of CLE.

The DPPH radical-scavenging activities of CLE were investigated. Vit. C ( $1 \mathrm{mg} / \mathrm{mL}$ ) was used as a positive control. The CLE between 0.1 to $10 \mathrm{mg} / \mathrm{mL}$ dose-dependently scavenged DPPH radicals. $\mathrm{IC}_{50}$ of CLE against DPPH radicals was $4.96 \mathrm{mg} / \mathrm{mL}$. Data are presented as the means of triplicate experiments with standard deviation. Different letters indicate significant differences by t-test ( ${ }^{*} p<0.05$ and ${ }^{* * *} p<0.001$ ). DPPH, 2,2-diphenyl-1-picrylhydrazyl; CLE, Curcuma longa L. extracts; Vit. C, vitamin C; $I_{50}$, half maximal inhibitory concentration.

primer sequences는 Table 1에 제시하였다. RNA 발현수준은 RT$\mathrm{PCR}$ 을 통하여 평가하였으며, 이를 정량적으로 알아보기 위해 Image $\mathrm{J}$ 프로그램(National Institutes of Health, USA)을 사용하였다.

\section{7. 통계분석}

본 연구의 결과는 mean \pm standard deviation으로 표현하였으 며, 실험결과의 통계 분석은 Statistical Package for Social Science (SPSS; IBM, USA) 프로그램을 이용하여 분석하였다. 통계결과의 사후검증은 Student's t-test 방법에 의하여 각 구간의 유의성 차이 를 검증하였다 $(p<0.05)$.

\section{Results and Discussion}

\section{CLE의 DPPH 라디칼 소거활성}

$\mathrm{DPPH}$ 라디칼 소거법은 항산화 물질의 전자 및 수소공여능을 측 정하는 방법으로 널리 이용된다. CLE의 항산화 활성을 평가하기 위하여 $\mathrm{DPPH}$ 라디칼 소거활성을 실험하였다. 양성 대조군으로는 수용성 항산화제로 잘 알려진 vitamin $\mathrm{C}$ 를 사용하였다. Vitamin $\mathrm{C}$ 는 $1 \mathrm{mg} / \mathrm{mL}$ 에서 $\mathrm{DPPH}$ 라디칼을 $100.00 \%$ 소거하였다. CLE는 $0.1,0.5,1,2.5,5,10 \mathrm{mg} / \mathrm{mL}$ 에서 각각 $4.46 \%, 4.97 \%, 3.02 \%$, $24.97 \%, 51.37 \%, 53.35 \%$ 의 DPPH 라디칼 소거능을 나타내었다. CLE $2.5,5,10 \mathrm{mg} / \mathrm{mL}$ 처리는 CLE $0.1 \mathrm{mg} / \mathrm{mL}$ 농도와 비교하 여 유의적으로 높은 $\mathrm{DPPH}$ 라디컬 소거활성을 나타냈다(Figure 2). $\mathrm{DPPH}$ 라디칼을 $50 \%$ 저해하는 농도인 CLE의 half maximal

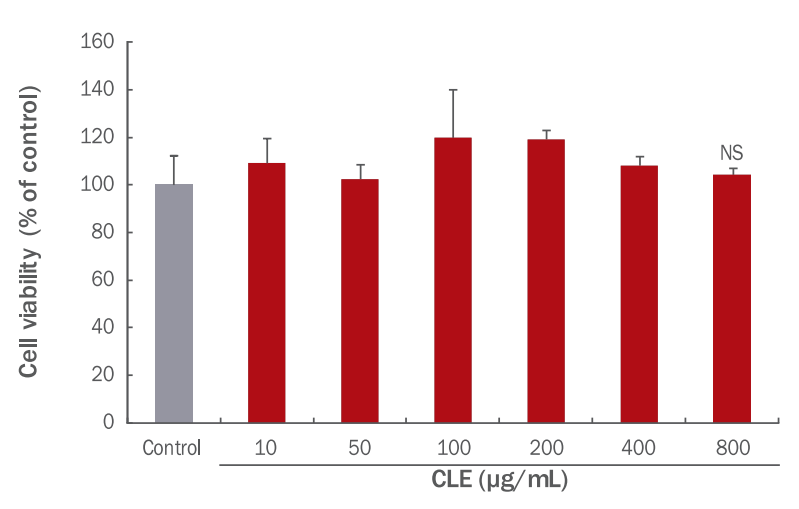

Figure 3. Effects of CLE on the 3T3-L1 viability.

3T3-L1 adipocytes viability was evaluated by MTT assay. 3T3-L1 adipocytes were treated with 10,50,100, 200,400, and 800 $\mathrm{\mu g} / \mathrm{mL}$ of CLE for $24 \mathrm{~h}$ and up to $800 \mu \mathrm{g} / \mathrm{mL}$ CLE for $24 \mathrm{~h}$ did not affect 3T3-L1 viability. Up to $800 \mu \mathrm{g} / \mathrm{mL}$ of CLE were used further experiment. Data are present means of triplicate experiments with standard deviation. CLE, Curcuma longa L. extracts; Control, CLE untreated group; NS, not significant; MTT, thiazolyl blue tetrazolium bromide.

inhibitory concentration $\left(\mathrm{IC}_{50}\right)$ 은 $4.96 \mathrm{mg} / \mathrm{mL}$ 로 나타났다. 이전 연구들을 보면 생강과 식물들이 DPPH 라디칼 소거활성을 나타냈 으며(Jung et al., 2012), 고지방, 고콜레스테롤 식이를 한 쥐에서 울금이 조직의 산화적 스트레스를 감소시켜 항산화 활성을 나타낸 다고 보고된 바 있다(Kim et al., 2013b). 따라서 울금 추출물은 체 내 활성산소의 증가를 억제하여 산화적 스트레스를 감소시킬 수 있 는 항산화 소재로 생각된다.

\section{3T3-L1 세포에서 CLE의 세포독성 평가}

CLE가 3T3-L1 전지방세포에 독성을 나타내는지 알아보기 위하 여 MTT assay를 실시하여 세포생존율을 분석하였다. CLE를 10, $50,100,200,400,800 \mu \mathrm{g} / \mathrm{mL}$ 의 농도범위로 전지방세포에 $24 \mathrm{~h}$ 동안 처리하였을 때, CLE가 처리된 3T3-L1 전지방세포의 생존율 은 각각 $109.08 \%, 102.61 \%, 120.05 \%, 119.06 \%, 108.10 \%, 104.40 \%$ 로 나타났다(Figure 3). 결과적으로 $10-800 \mu \mathrm{g} / \mathrm{mL}$ 농도의 CLE는 유의적인 세포독성을 나타내지 않았으므로, 이후 실험에서는 800 $\mu \mathrm{g} / \mathrm{mL}$ 이하의 농도에서 실험을 진행하였다.

\section{3T3-L1 전지방세포의 adipogenesis에 CLE가 미치는 영향}

Figure 1과 같이 3T3-L1 전지방세포를 분화시키고 CLE를 8일 동안 처리한 후 day 6 에 $\mathrm{ORO}$ 염색을 통해 지방 축적 정도를 측정 하였다. 현미경을 통해 지방 축적 정도를 확인한 결과, 지방 유도 를 시키지 않은 전지방세포에서는 지방구가 관찰되지 않았으며, 유 도시킨 대조군의 지방세포에서는 다량의 큰 지방구가 관찰되었다. $\mathrm{CLE}$ 처리 농도 중 $200,400,800 \mu \mathrm{g} / \mathrm{mL}$ 에서는 대조군과 비교하 여 지방구 크기 및 수가 농도 의존적으로 감소하는 모습이 관찰되 
A

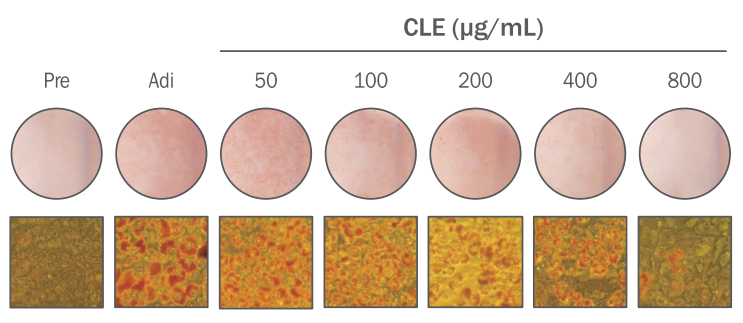

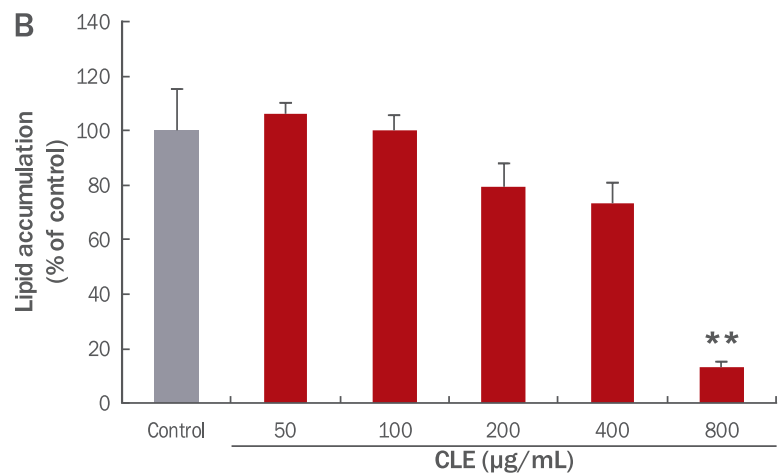

Figure 4. Effects of CLE on the 3T3-L1 adipogenesis.

The 3T3-L1 cells were treated with 50, 100, 200, 400, and $800 \mu \mathrm{g} / \mathrm{mL}$ of CLE from days -2 to 6 . The level, number, and size of lipid droplets in 3T3-L1 adipocytes in the presence or absence of CLE were analyzed by photomicrographed method. The CLE treatment effectively decreased the size and number of lipid droplets in 3T3-L1 adipocytes (A). The level of lipid accumulation in 3T3-L1 adipocyte was quantified at $510 \mathrm{~nm}$. The $800 \mu \mathrm{g} / \mathrm{mL}$ of CLE significantly inhibited intracellular lipid accumulation of 3T3-L1 adipocytes (B). Data are present means of triplicate experiments with standard deviation. Different letters indicate significant differences by t-test $\left({ }^{* *} p<0.01\right)$. CLE, Curcuma longa L. extracts; Pre, 3T3-L1 preadipocyte at day 6; Adi, mature adipocytes at day 6; Control, mature adipocytes at day 6.

었다(Figure 4A). CLE 처리를 한 지방세포를 대조군인 CLE를 처 리하지 않은 지방세포와 비교하였을 때 $50,100 \mu \mathrm{g} / \mathrm{mL}$ 의 농도처 리에서는 지방 축적 감소가 일어나지 않았으나 $200,400,800 \mu \mathrm{g} /$ $\mathrm{mL}$ 농도의 $\mathrm{CLE}$ 처리 시, 대조군과 비교하였을 때 농도 의존적으 로 $79.35 \%, 73.43 \%, 13.17 \%$ 의 수치만큼 지방 축적 함량을 감소시 키는 모습을 관찰할 수 있었다. 또한 $800 \mu \mathrm{g} / \mathrm{mL}$ 에서는 유의적으 로 지방 축적 함량을 감소시켰음을 확인할 수 있었다(Figure $4 \mathrm{~B}$ ). 비만은 전지방세포의 분화유도과정인 adipogenesis 과정에 의해 발생하는 것이며, 이 과정에 관여하는 여러 기전을 조절하는 것이 비만을 예방하는데 있어 중요한 요소임이 보고된 바 있다(Chen \& Farese, 2005). 이전 연구에 따르면 고콜레스테롤 식이로 유도된 고콜레스테롤혈증 쥐에서 울금 추출물이 음성대조군에 비하여 콜 레스테롤 농도가 감소하는 효과를 나타냈다(Kim et al., 2008). 본 실험 결과는 CLE가 3T3-L1 adipogenesis 과정 중 생성되는 지방 축적을 억제시킴으로써 항비만에 효과적일 것이라고 보여진다.

\section{CLE가 adipogenesis 관련 유전자 발현에 미치는 영향}

3T3-L1 전지방세포가 지방세포로 분화되는 adipogenesis 과정 에는 초기, 중기, 후기 세가지 단계별로 여러 분화 조절인자들이 관 여한다. Adipogenesis 관련 유전자 발현은 분화 초기에는 $C E B P B$ 와 $C E B P D$ 가 관여하며, 중기분화에는 $P P A R G$ 와 $C E B P A$ 를 중심으 로 여러 인자들이 복합적으로 작용하여 분화가 시작된다. 이와 같 이 CLE가 3T3-L1 세포의 adipogenesis에 관여하는 주요 인자들의 발현 조절 유무에 어떠한 영향을 미치는지 알아보기 위해 RT-PCR 을 통해 mRNA 발현수준을 분석하였다. 세포분화 조건은 Figure 1 과 동일하게 실시하였다. 대조군은 $A C T B$ 로 설정하였으며 $C E B P B$, $P P A R G, C E B P A, F A S N, L P L$ 순서로 실험을 진행하였다. 전지방
세포에 비해 분화된 지방세포에서의 $C E B P B, P P A R G, C E B P A$, $F A S N, L P L$ 의 mRNA 발현수준은 크게 증가하였으며 10,100 , $200,400 \mu \mathrm{g} / \mathrm{mL}$ 의 농도로 CLE를 처리하였을 때 대조군인 지방 세포에 비해 $\mathrm{mRNA}$ 발현수준이 감소하는 경향을 나타냈다(Figure $5 \mathrm{~A})$. 초기 전사인자인 $C E B P B$ 가 대조군인 adipocyte의 $A C T B$ 기 준값과 계산하여 비교하였을 때 $200,400 \mu \mathrm{g} / \mathrm{mL}$ 농도에서 그 이 하 농도에 비해 크게 감소하였으며, 초기 전사인자에 영향을 받는 중기분화 관련 전사인자인 $P P A R G$ 와 $C E B P A$, 그리고 후기에 발현 되는 대표적 유전자인 $F A S N$ 과 $L P L$ 역시 200 및 $400 \mu \mathrm{g} / \mathrm{mL}$ CLE 처리에서 발현이 감소하는 것을 관찰하였다(Figure $5 \mathrm{~B}$ ).

Adipogenesis는 관련 전사인자의 발현되는 양, 시기, 그리고 전사인자간의 상호조절작용을 통하여 밀접하게 조절된다. 이중 $\mathrm{CEBPB}$ 는 adipogenesis 초기단계에 발현되는 전사인자 중의 하나 로 adipogenesis의 초기 전사활성화 과정에 있어서 중요하다. 이 는 다음 단계의 분화과정을 촉진시키는 $\mathrm{PPARG}$ 와 $\mathrm{CEBPA}$ 의 발 현을 유도한다고 알려져 있다(Attie \& Scherer, 2009; Rosen \& MacDougald, 2006). Adipogenesis 과정의 전사인자들에 관한 이 전 연구에서는 발효 울금(fermented water extracts of Curcuma longa radix) 추출물에 의해 $P P A R G$ 의 발현이 감소되었으며(Kang et al., 2015), 식방풍잎 물 추출물은 부고환 지방조직에서 $P P A R G$, sterol regulatory element binding transcription factor 1 (SREBP1) 그리고 $F A S N$ 의 발현을 감소시킴으로써 체지방 축적 감소에 효과 가 있었다(Jung et al., 2016). 또한 머루근 추출물의 용매 분획물을 이용하였을 때 $C E B P A, C E B P B$, 그리고 $P P A R G$ 의 adipogenesis 과정의 주요 핵심 조절인자의 발현 감소를 통하여 항비만 활성을 증명한 바 있다(Park et al., 2013). 이러한 선행연구는 천연물 처리 를 통하여 지방세포 특이적 전사인자의 발현을 조절하는 것은 지방 
A

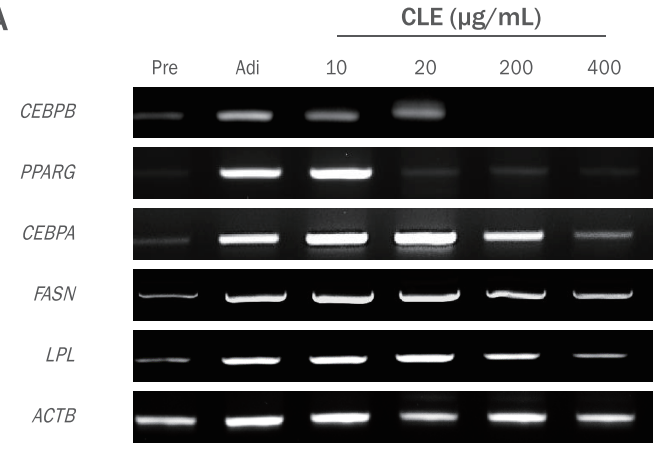

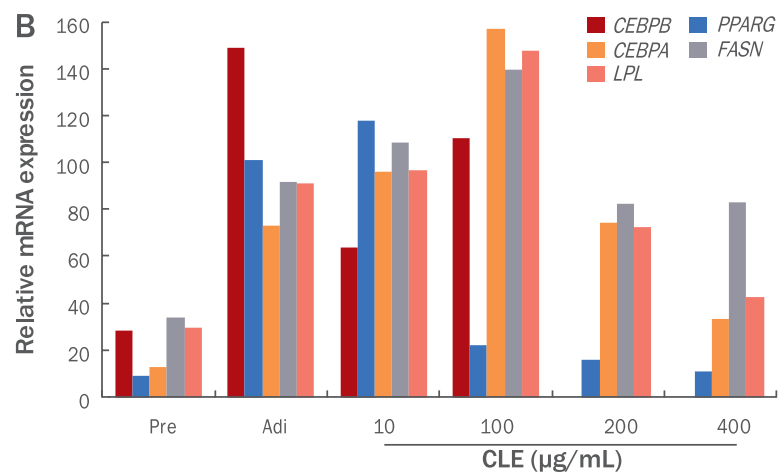

Figure 5. Effects of CLE on mRNA expression in 3T3-L1 adipocytes.

Adipogenesis in 3T3-L1 adipocytes is accompanied by increased expression of transcriptional factors and adipocyte-specific genes. The mRNA expression levels of adipogenic transcriptional factors including CEBPB, PPARG, CEBPA, FASN, and LPL were analyzed by RT-PCR. Their expression levels were suppressed by CLE treatment (A). The mRNA expression was quantified using Image J program (B). Each value of the graph corresponds to the percent divided by ACTB, an internal control. CLE, Curcuma longa L. extracts; Pre, 3T3L1 preadipocyte at day 6; Adi, mature adipocytes at day 6; CEBPB, CCAAT/enhancer binding protein $\beta ;$ PPARG, peroxisome proliferator activated receptor $\gamma ; C E B P A$, CCAAT/enhancer binding protein $\alpha ; F A S N$, fatty acid synthase; LPL, lipoprotein lipase; ACTB, actin beta; RT$\mathrm{PCR}$, reverse transcription-polymerase chain reaction.

조직의 축적과 밀접한 연관이 있음을 의미한다. 본 연구에서 CLE 는 3T3-L1 지방세포에서 adipogenesis 과정에 있어 중요한 전사 인자들의 발현을 감소시킴으로써 지방구 크기 및 수에 억제 효과를 나타내어 항비만 소재로 활용이 가능함을 알 수 있다.

\section{Conclusion}

비만은 체내에 체지방이 과도하게 축적된 상태를 의미하며 정신 적, 육체적, 그리고 사회적 요인의 영향을 받는다(Ji et al., 2012). 또한 비만은 고혈압, 심혈관, 그리고 당뇨병 등의 여러 대사증후군 의 발병과 밀접한 관련이 있는 것으로 알려져 있다. 비만의 경우 지 방세포에서 정상에 비해 매우 많은 양의 유리지방산이 기초 지방분 해율에 의해 다량으로 만들어진다(Choi et al., 2013). 이러한 유리 지방산이 증가하게 되면 활성산소종 생산이 증가하게 되어 세포에 독성을 일으키게 된다고 알려져 있으며, 결국 많은 질환의 발병과 밀접한 관련이 있다(Ward, 1991). 이러한 이유들로 항비만 연구에 서 항산화 활성을 같이 평가하고 측정되어야 할 것으로 생각된다.

전지방세포가 지방세포로 분화되는 과정을 adipogenesis라고 하 는데, 이 과정을 조절하는 것은 비만연구에 있어 중요한 목표이며, 그 기전을 정확히 규명하는 것은 향후 소재의 안전성을 확인하는 데 중요한 부분으로 생각된다.

본 연구에서는 $\mathrm{DPPH}$ 라디칼 소거활성을 통하여 국내 진도산 울 금 추출물(CLE)의 항산화 활성을 평가하였다. 또한, CLE를 3T3L1 세포에 day -2 에서 day 6까지 처리한 결과 CLE는 농도 의존 적으로 지방 축적을 감소시키는 것을 관찰 할 수 있었으며, 이 과
정 동안 CLE는 adipogenesis의 분화과정에 관여하는 주요 전사인 자인 $C E B P B, P P A R G, C E B P A, F A S N$, 그리고 $L P L$ 유전자 발현 을 효과적으로 억제하였다. 이러한 연구결과는 CLE가 효과적으로 adipogenesis를 억제하고, 향후 항비만 미용 식품 소재로서의 가능 성을 보여주는 결과로 생각된다. 향후 CLE의 항비만 활성이 어떠 한 분자생물학적 신호전달체계를 통해 전사인자들을 조절하는지에 대한 추가연구가 요구된다.

\section{Acknowledgements}

본 연구는 산업통상자원부와 한국산업기술진흥원의 "지역특화 산업육성사업”(과제번호 R0005174)으로 수행된 연구결과 입니다.

\section{References}

Attie AD, Scherer PE. Adipocyte metabolism and obesity. The Journal of Lipid Research, 50: 395-399, 2009.

Barry J, Fritz M, Brender JR, Smith PE, Lee DK, Ramamoorthy A. Determining the effects of lipophilic drugs on membrane structure by solid-state NMR spectroscopy: the case of the antioxidant curcumin. Journal of the American Chemical Society, 131: 4490-4498, 2009.

Cao Z, Umek RM, McKnight SL. Regulated expression of three C/EBP isoforms during adipose conversion of 3T3-L1 cells. Genes \& Development, 5: 1538-1552, 1991.

Chen HC, Farese RV Jr. Inhibition of triglyceride synthesis as 
a treatment strategy for obesity: lessons from DGAT1deficient mice. Arteriosclerosis, Thrombosis, and Vascular Biology, 25: 482-486, 2005.

Chen HM, Muramoto K, Yamauchi F, Fujimoto K, Nokihara K. Antioxidative properties of histidine-containing peptides designed from peptide fragments found in the digests of a soybean protein. Journal of Agricultural and Food Chemistry, 46: 49-53, 1998.

Chen Z, Torrens Jl, Anand A, Spiegelman BM, Friedman JM. Krox20 stimulates adipogenesis via C/EBPbetadependent and -independent mechanisms. Cell Metabolism, 1: 93-106, 2005.

Choi JH, Park YH, Lee IS, Lee SP, Yu MH. Antioxidant activity and inhibitory effect of Aster scaber Thunb. extract on adipocyte differentiation in 3T3-L1 cells. Korean Journal of Food Science and Technology, 45: 356-363, 2013.

Choi KM, Lee YS, Kim W, Choi YH, Kwak YG, Jung JC, Lee J, Yoo HS. Improvement of high-fat diet-induced obesity by xanthigen in C57BL/6N mice. Journal of Life Science, 22: 1697-1703, 2012.

Chua S Jr, Leibel RL. Obesity genes: molecular and metabolic mechanisms. Diabetes Reviews, 5: 2-7, 1997.

de Ferranti S, Mozaffarian D. The perfect storm: obesity, adipocyte dysfunction, and metabolic consequences. Clinical Chemistry, 54: 945-955, 2008.

Evans JL, Goldfine ID, Maddux BA, Grodsky GM. Oxidative stress and stress-activated signaling pathways: a unifying hypothesis of type 2 diabetes. Endocrine Reviews, 23: 599-622, 2002.

Holst D, Grimaldi PA. New factors in the regulation of adipose differentiation and metabolism. Current Opinion in Lipidology, 13: 241-245, 2002.

Jakoby WB. The glutathione S-transferases: a group of multifunctional detoxification proteins. Advances in Enzymology and Related Areas of Molecular Biology, 46: 383-414, 1978.

Jelodar GA, Maleki M, Motadayen MH, Sirus S. Effect of fenugreek, onion and garlic on blood glucose and histopathology of pancreas of alloxan-induced diabetic rats. Indian Journal of Medical Sciences, 59: 64-69, 2005.

Ji HH, Jeong HY, Jin S, Kwon HJ, Kim BW. Inhibition of adipocyte differentiation by methanol extracts of Oenanthe javanica seed in 3T3-L1 preadipocytes. Journal of Life Science, 22: 1688-1696, 2012.

Jung HK, Sim MO, Jang JH, Kim TM, An BK, Kim MS, Jung WS. Anti-obesity effects of Peucedanum japonicum Thunberg L. on 3T3-L1 cells and high-fat diet-induced obese mice. Korean Journal of Plant Resources, 29: 1-10, 2016.

Jung YS, Park SJ, Park JH, Jhee KH, Lee IS, Yang SA. Effects of ethanol extracts from Zingiber officinale Rosc., Curcuma longa L., and Curcuma aromatica Salisb. on acetylcholinesterase and antioxidant activities as well as GABA contents. Journal of the Korean Society of Food Science and Nutrition, 41: 1395-1401, 2012.

Kang YH, Kim KK, Kim TW, Yang CS, Choe M. Evaluation of the anti-obesity activity of Platycodon grandiflorum root and Curcuma longa root fermented with Aspergillus oryzae. Korean Journal of Food Science and Technology, 47: 111-118, 2015.

Kim HO, Hwang YI, Kim GN. Anti-obese function of demethoxycurcumin through suppression of adipogenesis in 3T3-L1 cells. Asian Journal of Beauty and Cosmetology, 11: 29-34, 2013a.

Kim MS, Chun SS, Choi JH. Effects of turmeric (Curcuma longa L.) on antioxidative systems and oxidative damage in rats fed a high fat and cholesterol diet. Journal of the Korean Society of Food Science and Nutrition, 42: 570576, 2013b.

Kim TH, Son YK, Hwang KH, Kim MH. Effects of Angelica keiskei Koidzumi and turmeric extract supplementation on serum lipid parameters in hypercholesterolemic diet or P-407-induced hyperlipidemic rats. Journal of the Korean Society of Food Science and Nutrition, 37: 708713, 2008.

Koutnikova H, Auwerx J. Regulation of adipocyte differentiation. Annals of Medicine, 33: 556-561, 2001.

Lee JA, Ahn EK, Hong SS, Oh JS. Anti-obesity effect of ethyl acetate extracts from Agrimonia pilosa Ledeb. in 3T3L1 preadipocytes. Journal of the Korean Society of Food Science and Nutrition, 41: 161-167, 2012a.

Lee KJ, Ma JY, Kim YS. Identification of curcuminoids from turmeric (Curcuma longa) using ultrasonic wave and dipping method. Korean Society for Biotechnology and Bioengineering Journal, 27: 33-39, 2012b.

Morrison RF, Farmer SR. Hormonal signaling and transcriptional control of adipocyte differentiation. The Journal of Nutrition, 130: 3116S-3121S, 2000. 
Mudduluru G, George-William JN, Muppala S, Asangani IA, Kumarswamy R, Nelson LD, Allgayer H. Curcumin regulates miR-21 expression and inhibits invasion and metastasis in colorectal cancer. Bioscience Reports, 31: 185-197, 2011.

Park JA, Jin KS, Oh YN, Hyun SK, Choi YH, Kwon HJ, Kim BW. Antiadipogenic effect of Vitis amurensis root methanol extract and its solvent fractions in 3T3-L1 preadipocytes. Journal of Life Science, 23: 69-78, 2013.

Rosen ED, MacDougald OA. Adipocyte differentiation from the inside out. Nature Reviews Molecular Cell Biology, 7: 885896, 2006.

Rosen ED, Spiegelman BM. Molecular regulation of adipogenesis. Annual Review of Cell and Developmental Biology, 16: 145-171, 2000.
Salla S, Sunkara R, Ogutu S, Walker LT, Verghese M. Antioxidant activity of papaya seed extracts against $\mathrm{H}_{2} \mathrm{O}_{2}$ induced oxidative stress in HepG2 cells. LWT-Food Science and Technology, 66: 293-297, 2016.

Ward PA. Mechanisms of endothelial cell injury. Translational Research, 118: 421-426, 1991.

Zhang JW, Klemm DJ, Vinson C, Lane MD. Role of CREB in transcriptional regulation of CCAAT/enhancer-binding protein beta gene during adipogenesis. The Journal of Biological Chemistry, 279: 4471-4478, 2004. 


\section{국문초록}

\section{지방세포 특이적 전사인자 조절을 통한 울금 추출물의 항비만 활성}

이성애 ${ }^{1}$, 주형진 $^{1}$, 박민준 $^{1}$, 박부덕 $^{2}$, 김교남 ${ }^{1 *}$

${ }^{1}$ 경남대학교 식품영양생명학과, 경상남도 창원시, 한국

${ }^{2}$ 발효촌, 경상북도 경산시, 한국

목적: 울금(Curcuma longa L.)은 항산화, 항암, 그리고 항염 등 다양한 생리활성이 보고되어 있지만, 미용관련 기능성 평가는 상대 적으로 미비한 실정으로, 본 연구에서는 국내 진도산 울금 추출물(Curcuma longa L. extracts, CLE)의 항산화 및 3T3-L1에서의 항비만 활성 평가를 통해 미용기능식품 소재로서의 가능성에 대해 알아보고자 하였다. 방법: CLE의 항산화 활성은 2,2-diphenyl1-picrylhydrazyl (DPPH) 라디칼 소거능을 통하여 평가하였으며, 세포독성은 thiazolyl blue tetrazolium bromide (MTT) assay를 이 용하였다. 또한 CLE의 지방 축적 억제활성은 3T3-L1를 day -2에서 day 6까지 총 8일 동안 분화시키면서 CLE를 처리하고 Oil Red $\mathrm{O}(\mathrm{ORO})$ 염색법을 통해 정량분석 하였다. 또한 현미경 관찰 및 이미지 분석을 통해 지방구의 수 및 크기의 변화를 정성분석 하였 다. CLE가 3T3-L1 세포의 지방세포분화에 관여하는 전사인자들의 mRNA 발현수준은 reverse transcription-polymerase chain reaction (RT-PCR)을 통해 분석하였다. 결과: CLE는 농도 의존적으로 DPPH 라디칼을 소거하였다. 3T3-L1 전지방세포에 CLE 를 $24 \mathrm{~h}$ 동안 처리하였을 때, $800 \mu \mathrm{g} / \mathrm{mL}$ 이하의 농도에서 세포생존율에 영향을 미치지 않았으며, 이후 실험에서 $800 \mu \mathrm{g} / \mathrm{mL}$ 이하의 농 도로 실험을 진행하였다. CLE가 처리된 3T3-L1 세포의 지방 축적 함량은 농도 의존적으로 감소되었으며, 지방구의 크기 및 수도 감소 되었다. 또한 adipogenesis에 관여하는 주요 전사인자 및 유전자가 CLE에 의해 농도 의존적으로 발현이 감소하였다. 결론: 본 연구는 CLE가 항산화 및 항비만 활성을 가진 화장품 및 미용식품 소재로 충분히 활용될 수 있을 것이라 제안한다.

핵심어: 울금, 비만, 지방세포분화, 항산화, 산화적 스트레스

본 연구는 산업통상자원부와 한국산업기술진흥원의 “지역특화산업육성사업”(과제번호 R0005174)으로 수행된 연구결과 입니다.

\section{참고문헌}

강윤환, 김경곤, 김태우, 양춘수, 최면. 도라지, 울금의 Aspergillus oryzae 발효에 의한 항비만효과 연구. 한국식품과학회지, 47: 111-118, 2015.

김민선, 전성식, 최정화. 울금(Curcuma longa L.)이 고지방 - 고콜레스테롤 식이 흰쥐의 항산화계 및 산화적 손상에 미치는 영향. 한국식품영양과학회지, $42: 570-576,2013 \mathrm{~b}$.

김태현, 손연경, 황금희, 김미현. 명일엽과 울금 추출물의 투여가 고콜레스테롤식이와 P-407로 유도한 고지혈증쥐의 혈중 지

질 함량에 미치는 영향. 한국식품영양과학회지, 37: 708-713, 2008.

김혜옥, 황용일, 김교남. 3T3-L1 세포에서 Adipogenesis 조절을 통한 Demethoxycurcumin의 항비만 활성. 아시안뷰티화장 품학술지, 11: 29-34, 2013a.

박정애, 진경숙, 오유나, 현숙경, 최영현, 권현주, 김병우. 머루근 추출물 및 분획물의 항비만 활성. 생명과학회지, 23: $69-$ 78, 2013.

이정아, 안은경, 홍성수, 오좌섭. 3T3-L1 지방전구세포에서 용아초 에틸아세테이트 추출물의 항비만 효과. 한국식품영양과 학회지, 41: 161-167, 2012a.

정연섭, 박성진, 박정현, 지광환, 이인선, 양선아. 생강, 울금, 강황 추출물의 항산화 효과, $\mathrm{AChE}$ 억제활성 및 $\mathrm{GABA}$ 함량.

한국식품영양과학회지, 41: 1395-1401, 2012.

정호경, 심미옥, 장지훈, 김태묵, 안병관, 김민석, 정원석. 식방풍잎(Peucedanum japonicum Thunberg L.)의 물추출물이 
3T3-L1 세포와 고지방식이로 유도된 마우스에서 항비만 효과. 한국자원식물학회지, 29: 1-10, 2016.

지향화, 정현영, 진수정, 권현주, 김병우. 돌미나리씨 추출물에 의한 3T3-L1 지방전구세포의 분화 억제. 생명과학회지, 22 : 1688-1696, 2012.

최경미, 이윤선, 김원균, 최영현, 곽연길, 정재철, 이정래, 유환수. 잔티젠(Xanthigen)에 의한 고지방식이로 유도된 비만 개선 효과. 생명과학회지, 22: 1697-1703, 2012.

최준혁, 박윤희, 이인선, 이삼빈, 유미희. 참취(Aster scaber Thunb.) 추출물의 항산화 효과와 3T3-L1 지방전구세포에서의 지방분화 억제 효과. 한국식품과학회지, 45: 356-363, 2013. 


\section{中文摘要}

\section{姜黄提取物通过调节脂肪细胞的特异性转录因子的抗肥胖活性}

李成愛 ${ }^{1}$, 朱亨眞 $^{1}$, 朴慜峻 $^{1}$, 朴富德 ${ }^{2}$, 金墝男 $^{{ }^{*}}$

忠庆南大学食品营养生命学科, 庆尚南道昌原市, 韩国

2发酵村，庆尚北道庆山市，韩国

目的：姜黄（Curcuma longa L.）被报道具有抗氧化,抗癌以及抗炎等多种生理活性,但美容相关功能性评价的研究相对很 少。因此探讨韩国国产姜黄提取物（Curcuma longa L. extracts, CLE）的抗氧化以及在3T3-L1细胞的抗肥胖活性, 调查其 作为美容功能性食品原料的应用可行性。方法：CLE的抗氧化活性，利用2,2-diphenyl-1-picrylhydrazyl（DPPH）自由基 消除能力来检测, 利用thiazolyl blue tetrazolium bromide (MTT) assay法来检测细胞毒性。为检测CLE的脂肪堆积抑制 活性, 将3T3-L1细胞从day -2到day 6总共分化8日并用CLE处理, 利用Oil Red O (ORO) 染色法定量分析。此外, 通过显 微镜观察以及图像分析, 定性分析脂肪球的数量和大小变化。利用 reverse transcription-polymerase chain reaction（RTPCR）法检测CLE对3T3-L1细胞中与脂肪细胞分化相关的转录因子mRNA表达水平。结果：CLE按浓度依赖性消除DPPH自 由基。对3T3-L1前脂肪细胞用CLE $24 \mathrm{~h}$ 处理时, 在 $800 \mu \mathrm{g} / \mathrm{mL}$ 以下浓度时, 对细胞生存率不产生影响, 因此以后实验中采 用 $800 \mu \mathrm{g} / \mathrm{mL}$ 以下的浓度。被CLE处理的3T3-L1细胞的脂肪堆积含量, 按浓度依赖性逐渐减少, 脂肪球的大小和数量也减 少。与脂肪形成相关的转录因子和遗传因子的表达, 也按浓度依赖性逐渐减少。结论: 通过以上研究, CLE作为抗氧化和 抗肥胖活性的化妆品以及美容食品原料充分具有应用可行性。

关键词: 姜黄，肥胖，脂肪细胞分化，抗氧化，氧化应激 